Volume 9, No.1, January - February 2020

International Journal of Advanced Trends in Computer Science and Engineering

Available Online at http://www.warse.org/IJATCSE/static/pdf/file/ijatcse28912020.pdf

https://doi.org/10.30534/ijatcse/2020/28912020

\title{
Development and Implementation of Web-based Paperless Student Evaluation for Teachers (PSET)
}

\author{
Irma T. Plata, John M. Facun \\ College of Computing Studies, Information and Communication Technology \\ Isabela State University, Philippines \\ irma.t.plata@isu.edu.ph
}

\begin{abstract}
This study presents the development and implementation of fully operational Paperless Student Evaluation for Teachers (PSET), which is an innovative way to improve the evaluation process of students to their teachers. The Sequential Development Life Cycle Model served as a framework that involved planning, requirements analysis, design, development, implementation, and evaluation done sequentially. This study was piloted at Isabela State University, Echague Campus in the SY 2014-2015, and implemented during the ${ }^{\text {st }}$ Semester of SY 2015-2016 to present. During its pilot implementation, $87 \%$ of the total number of students utilized the system, while $74 \%$ of them participated in the survey to evaluate the technical usability of the system. Based on the findings of the study, the developed system provides a centralized e-repository of information utilized to collect, monitor, retrieve, distribute, store, report, and archive faculty evaluation data and results. The student-respondents favorably evaluated the PSET in terms of ease of use, simplicity, user-friendliness, efficiency, saving time, usefulness, learning to use, remembering, pleasant interface, and the overall satisfaction, thus the technical usability evaluation is highly acceptable and commendable.
\end{abstract}

The user of the PSET results can deliver timely manner of providing feedback to teachers. There will be sufficient time for students to give their feedback/comments. The identification of teachers' strengths and weaknesses so that the conduct of in-house training and students and teacher relations may be improved. More, the availability of results electronically for future use and identification of issues and concerns related to instruction such as managing classroom and behavior of teachers can be addressed.

Key words: Course evaluation, Higher Education Institution, Information systems, Paperless evaluation, Teaching effectiveness, Web-based system

\section{INTRODUCTION}

The students, teachers, and management are the major stakeholders of the educational processes, which they play a role in the development and improvement of the academic sector. Academic satisfaction is the outcome of both the management and the academic system's consistent performance, like providing an environment which facilitates conducive learning, providing ICT infrastructures, and ICT-enabled services like e-learning, online registration system, and online evaluation systems [1]. The students' satisfaction reflects the quality management in the University.

The conduct of teaching effectiveness and classroom performance evaluation aims to improve the course or teaching methodologies and strategies of teachers. Receiving valuable feedback or comments can be used to improve teachers' performance. More, the norm of online evaluation is just the same as the traditional way of evaluating teachers. According to literature, the teacher can less influence students while performing online assessments [2], [3], and more likely, some students perceive online evaluations as more anonymous than the traditional paper and pencil evaluation [4]. Uses of evaluation results are useful to higher management as decision-makers where it can serve as the basis for academic reviews, teacher performance reports, promotion or reclassification, teaching award, and accreditation reviews, among others.

The Isabela State University (ISU), a public Higher Education Institution established in 1978 with nine campuses and two extension campuses located in the province of Isabela, Cagayan Valley region [5]. In the school year 2015-2016, it has around 35,000 students enrolled in different disciplines/courses. In the Echague campus alone, there were about 7,800 students in the school year 2015-2016 from the eight various colleges/institutes. The University is motivated to cope with the changing needs of the academic arena to better improve instructions and client services to innovate teaching and learning tools for classroom use and provide quality education.

Before the development of a web-based system, the University is using the pen-and-paper evaluation system. The teacher's classroom performance in terms of knowledge of the subject, teaching for independent learning, management of education, and commitment to determine the teacher's teaching effectiveness is manually done. Near the end of each semester, teachers are being evaluated based on the number of students and subjects taught. Yet, it has been a long-time observation and practice that during the process, concerns related to the 
Irma T. Plata et al., International Journal of Advanced Trends in Computer Science and Engineering, 9(1), January - February 2020,186 - 193

timeliness of subject evaluation feedbacks, the processing time required to a large number of raw data, and the encoding of students' handwriting comments causes a delay in reporting the results to the teachers. Moreover, the manual process is tedious, difficult to conduct, extensive, and costly in terms of paper production, prone to possible human error when doing the reports, and limited staff to do the work.

Overall, the program chair is responsible for organizing, computing, and analyzing evaluations where he/she spends days or even weeks, depending on the bulk of evaluation questionnaires to be processed [6]. Also, feedbacks like comments and suggestions of students should be encoded as it was written in the paper to retain student's anonymity. More, the production and distribution of hard copies to higher management, and teachers are also done [6]. With the accomplished steps by the program chair, the development and implementation of the web-based evaluation system in the University is beneficial since it saves time, cost, human resource, and provides efficient, accurate, and timely reporting of results [7].

Ideally, results should be delivered to program heads/deans and forwarded to Higher Management immediately after students' ratings are processed. Through this process, management receives valuable information about the teacher's performance and the perceived effectiveness of each course. More, the results can be used by teachers to improve their courses and teaching skills.

Several types of research also served as a basis in the development of the system like the web-based faculty evaluation system to automate the evaluation process of the Apayao State College. Improving the accuracy of reports generated and the elimination of problems like the possible manipulation of evaluation results were addressed in the system [8]. At the University of Florida, they require students to complete the evaluation of courses and instructors by implementing an online course evaluation process. Also, at the University of Colorado, they obtained student feedback and perceptions about the courses and overall curriculum with the development and implementation of an online assessment system [9]. Further, Glotzbach, R. et al. [10] developed a web-based application for online instructor evaluation, which they include charting and graphing as added features of the app. In 2001, the College of Pharmacy of the University of Oklahoma used an online course evaluation system called CourseEval software (Academic Management Systems, Amherst, NY) (M. Medina, EdM, October 3, 2003). The system provided quick evaluation results using the online process. Thus faculty members were appreciative and satisfied with the evaluation tool.

More, the literature about online evaluation for teachers has several advantages identified like it provides feedback quickly, it is less expensive to administer in terms of implementation costs, and it requires less time to accomplish.
Also, it is less susceptible to teachers' influence; it provides results efficiently, accurately, and on time. And lastly, it allows students to evaluate multiple teachers at one time allotted schedule.

This study focused on the development and implementation of Web-based Paperless Student Evaluation for Teachers (PSET) for Isabela State University to address the problems encountered in the present system. The issues on security of information, confidentiality, and anonymity of teachers and students were addressed; implementing the system; and evaluating the usability of the system as perceived by the students.

\section{PROCEDURES AND METHODS}

\subsection{System Development and Implementation Process}

The Sequential Life Cycle Model served as a framework for the development and implementation of the system [11]. Figure 1 illustrates the model which involves the following phases: planning, requirements analysis, designing, development, implementation, and evaluation.

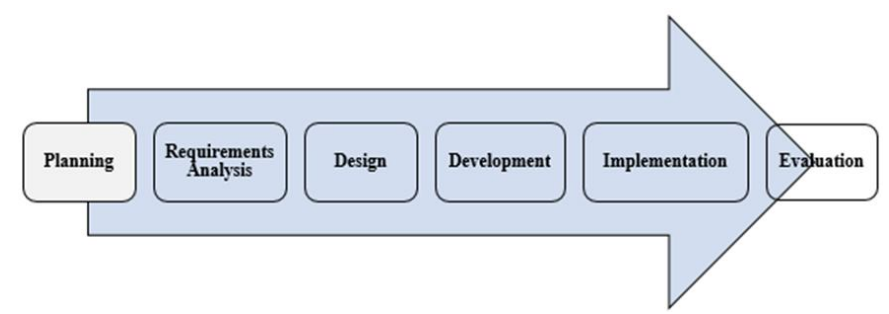

Figure 1: Phases of the sequential life cycle model in the development and implementation of the PSET

The Planning phase involved the conceptualization of the study. The Requirements analysis requires data gathering and determining information and functional requirements needed in the design and development of the system. The Design phase involved the design of the interfaces, databases, and hardware architecture based on the requirements and functions examined. The Development phase is the creation/building of the PSET with XAMPP as the development platform. PHP was used to develop the front-end of the system and MySQL for the database. The Implementation phase involved the actual utilization of the system, the conduct of users' training, and the set-up of resources and preparation of schedules. Conduct of series of testing to assess requirements and specifications are among its activities - more testing related to runability, compatibility, and interrelation of its functionality. The pilot testing also determines issues on the security of information, confidentiality, and anonymity of end-users. The Evaluation phase involved the evaluation of the system usability as perceived by the students.

\subsection{Respondents and Locale of the Study}

The study was conducted at the Isabela State University, Echague Campus. In SY 2014-2015, during the pilot 
Irma T. Plata et al., International Journal of Advanced Trends in Computer Science and Engineering, 9(1), January - February 2020, 186 - 193

implementation, the PSET took place in the College of Computing Studies (CCS) with around 700 students who took the evaluation. On its full-blown implementation in SY 2015-2016 and SY 2016-2017, there were eight Colleges involved with an average of 5,170 students who participated in the assessment from among the 7,800 students of the University. Table 1 presents the breakdown of student-respondents.

Table 1: Breakdown of student-respondents by College

\begin{tabular}{lcc}
\hline College & \multicolumn{2}{c}{$\begin{array}{c}\text { Number of Respondents } \\
\text { per College }\end{array}$} \\
\cline { 2 - 3 } & Students & Percentage \\
\hline College of Arts and Sciences & 817 & $15.80 \%$ \\
\hline $\begin{array}{l}\text { College of Bus. Accountancy } \\
\text { and Public Admin (CBAPA) }\end{array}$ & 2010 & $38.88 \%$ \\
\hline College of Agriculture & 437 & $8.45 \%$ \\
\hline College of Engineering & 507 & $9.81 \%$ \\
\hline College of Nursing & 62 & $1.20 \%$ \\
\hline College of Teacher Education & 842 & $16.29 \%$ \\
\hline $\begin{array}{l}\text { Institute of Information and } \\
\text { Communication Technology }\end{array}$ & 282 & $5.45 \%$ \\
\hline School of Vet. Medicine & 213 & $4.12 \%$ \\
\hline TOTAL & $\mathbf{5 1 7 0}$ & $\mathbf{1 0 0 \%}$ \\
\hline
\end{tabular}

\subsection{Methods of Data Collection}

The current flow of the teaching effectiveness evaluation procedures was analyzed to study the present information requirements and processes involved in the study as follows:

1. Prepare the schedule of evaluation visits to classes/sections as per the workload of teachers on the current semester.

2. Prepare and produce teaching effectiveness questionnaires based on the projected number of students per class/section/program.

3. Conduct/float evaluation per class/section.

4. Prepare spreadsheet template, setting formulas, and conditions.

5. Tabulate ratings, compute rating results, and initially analyze rating results based on the data encoded.

6. Encode comments/suggestions provided by the students based on how it was written in the paper-evaluation form.

7. Produce individual teacher evaluation report.

8. Produce a summary of teacher evaluation report per program, per college, and department.

9. Provide feedback through the conduct of post-conference to teachers based on the results of the evaluation.

10. Transmit evaluation report to higher management for information and necessary actions.

11. Keep both printed copies and electronic copies of the evaluation reports for future references.

As shown in Figure 2, the Entity-Relationship Diagram (ERD) was used to analyze the relationship of the different tables and fields of the web-based system. Before its development, the identification of functional and non-functional requirements of the web-based system produce the fully operational PSET at the end of the development period.

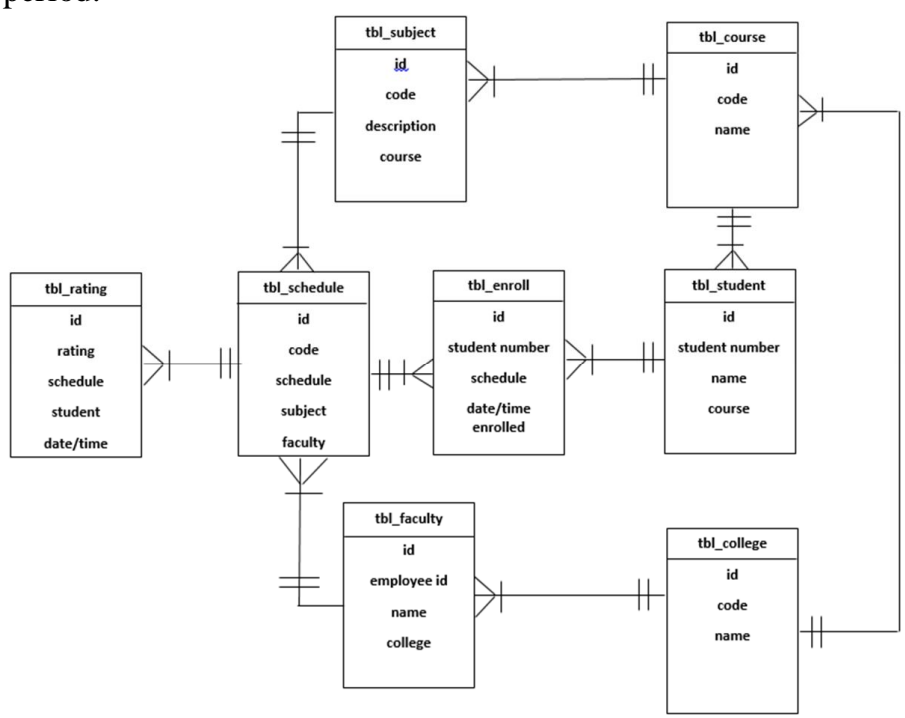

Figure 2: The Entity Relations Diagram (ERD) of the PSET

For implementation, approval was sought from the ISU Management to utilize the PSET in the conduct of the evaluation. The PSET was tested and piloted at the College of Computing Studies for the second semester, SY 2014-2015. Part of the testing and pilot implementation addressed some issues on security, confidentiality, and anonymity of users and information. Finally, the system was adopted for utilization/ implementation in the succeeding semesters in the eight colleges of the University. End-users supply a user name and password in accessing the system. System utilization privileges, roles, and levels of authority to access the system were given to end-users to address issues of confidentiality and anonymity of users and information.

In the conduct of technical usability to students, a survey instrument was prepared using Google form and uploaded online. The evaluation rubric is available and accessible online https://docs.google.com/spreadsheet/viewform?formkey=dG pTeTJwUIF2eGN3WHZIZFRULTRydmc6MQ.The instrument was adopted from the work of Elissavet and Economides [12] using the Likert scale, five being the highest which means "Strongly Agree" and one, the lowest which means "Strongly Disagree".

\subsection{User Roles and Functional Requirements of the PSET}

The development of PSET taking into consideration the requirements set as to delineation of end-users' tasks. There are three primary users identified, the system administrator, program chairman, and the students. Table 2 presents the role of primary users. 
Irma T. Plata et al., International Journal of Advanced Trends in Computer Science and Engineering, 9(1), January - February 2020,186 - 193

Table 2: Main Users of the PSET

\begin{tabular}{ll}
\hline User & Role \\
System & $\begin{array}{l}\text { Has the overall control of the system } \\
\text { in terms of managing and monitoring } \\
\text { the different modules like managing } \\
\text { curriculum, subjects, class schedules, } \\
\text { and uploading students' master list, } \\
\text { among others. }\end{array}$ \\
\hline Program & $\begin{array}{l}\text { Responsible for monitoring status per } \\
\text { program/college, updating records, }\end{array}$ \\
& $\begin{array}{l}\text { and printing of evaluation reports, } \\
\text { among others. }\end{array}$ \\
\hline Students & $\begin{array}{l}\text { The main clients/users of the system } \\
\text { responsible for evaluating their } \\
\text { teachers based on the subjects they } \\
\text { enrolled in the current semester. }\end{array}$ \\
\hline
\end{tabular}

The different functions of the PSET are:

1. Projection on the number of students and their percentage who took the evaluation per subject.

2. View and print a list of students who did not take the evaluation.

3. View and print a master list of enrolled students in different courses/subjects.

4. View and print Individual Evaluation Raw Data per Subject, including the comments/ suggestions provided by the students in portable document format (pdf).

5. Generation of Summary Teaching Effectiveness Evaluation Report with the General Weighted Average in portable document format (pdf)
a. Per College,
b. Per Department, and
c. Per Program

6. Generation of Summary Teaching Effectiveness Evaluation report as to Employment status

a. Evaluation report of Permanent Teachers

b. Evaluation report of Contract of Service (COS) Teachers

7. Modify, view, and print the Teaching Effectiveness Survey Questionnaire.

8. Identification of students who have not yet participated in the survey.

9. Level of access, privileges, and authorization of users (system administrator, program chairman, and students)

10. Provision of user accounts and passwords.

11. Transaction trail/tracking and user's logging access recorded in the system.

12. The system administrator can set-up/manage the following: College, Program, Curriculum, subjects, sections, and rating period to address changes in the management of the system.

13. Under the transaction module, the Administrator can register students, register teachers, and manage class and teachers' schedules.
14. The program chairman can set-up and update curriculum, manage subjects, register subjects, register teachers, manage schedules, can print reports, and list of students enrolled.

15. Students can view their profile, list of subjects enrolled, and access the evaluation for Teachers' Teaching Effectiveness form.

\section{RESULTS AND DISCUSSIONS}

\subsection{The Developed Web-based PSET 3.1.1 For the system administrator}

For the system administrator, there are three modules developed: the set-up module, transaction module, and report module. The figures below, Figure 3, Figure 4, and Figure 5, are sample screenshots of the PSET under the System Administrator Account with the various components/modules description and used presented in Table 3, Table 4, and Table 5 .

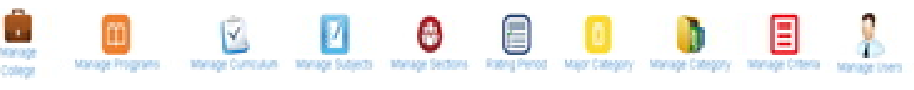

Figure 3: PSET Set-up Module of the System Administrator

Table 3: Different components/modules of the PSET Set-up for the Administrator

\begin{tabular}{ll}
\hline Components & Description \\
\hline Manage & Set-up module for different Colleges in the \\
College & University. \\
\hline Manage & Set-up module for different program/course \\
Program & offerings per College. \\
\hline Manage & Set-up module for varied curriculum per \\
Curriculum & program. \\
\hline Manage & Set-up different subject offerings per \\
Subjects & curriculum and per program. \\
\hline Manage & Set-up class and number of sections per year \\
Sections & level. \\
\hline Rating & Set-up rating period, identifying the \\
period & semester and school year (i.e., first \\
& semester, SY 2014-2015). \\
\hline Manage & Set-up the survey instrument/criteria for \\
Criteria & teaching effectiveness. \\
\hline Manage & Set-up users accounts, privileges, and \\
Users & authority in using the PSET. \\
\hline
\end{tabular}

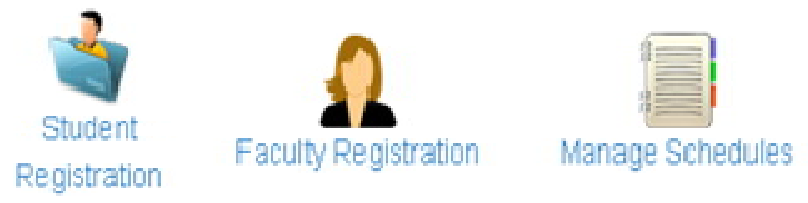

Figure 4: PSET Transaction module of the System Administrator 
Irma T. Plata et al., International Journal of Advanced Trends in Computer Science and Engineering, 9(1), January - February 2020,186 - 193

Table 4: Different Components/Modules of the PSET Transaction Module of the Administrator

\begin{tabular}{ll}
\hline Components & Description \\
\hline Student & Enlist students' information; bulk \\
Registration & enlistment uploaded/imported from the \\
& available students master list extracted \\
& from the Student Information and \\
& Accounting System (SIAS) used in the \\
& University. \\
\hline Faculty & Enlist faculty information; bulk enlistment \\
Registration & uploaded/imported from the available \\
& faculty master list extracted from the SIAS. \\
\hline Manage & Faculty and student class schedules were \\
Schedules & uploaded/imported from the available \\
& schedule of classes from the SIAS. \\
\hline
\end{tabular}
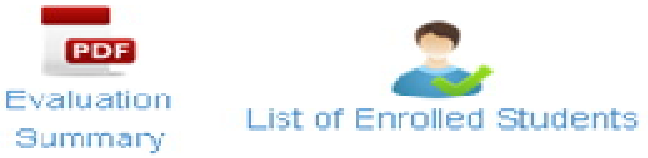

Figure 5: PSET Report module

Table 5: Different components/modules of the PSET Report Module of the Administrator

\begin{tabular}{ll}
\hline Components & Description \\
\hline Evaluation & $\begin{array}{l}\text { Automatic generation of Evaluation reports } \\
\text { produced in portable document format } \\
\text { (pdf); Summary Faculty evaluation, } \\
\text { Permanent and Contract of Service Faculty } \\
\\
\text { Evaluation, and Individual Faculty } \\
\text { Evaluation per Subject Evaluated including } \\
\text { the comments/ suggestions by the students. }\end{array}$ \\
& $\begin{array}{l}\text { The system generates a Masterlist of } \\
\text { List of } \\
\text { Enrolled }\end{array}$ \\
Students per subject.
\end{tabular}

\subsubsection{For the Program chairman}

Under the program chairman module, Figure 6 is a sample screenshot. The account has the following authorization and privileges of managing and monitoring the PSET, like Set-up, Transaction, and Report. Table 6 presents the different components and modules.

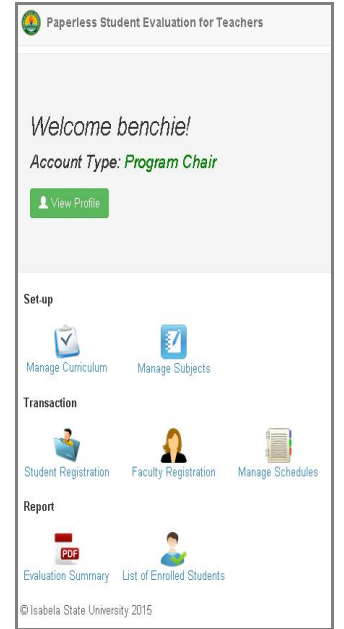

Figure 6: Program chair/college secretary PSET main page composed of set-up, transaction, and report modules

Table 6: Different components/modules of the PSET Set-up, Transaction, and Report Module for the Program Chair/Secretary

\begin{tabular}{|c|c|}
\hline Components & Description \\
\hline \multicolumn{2}{|c|}{ Set-up Module } \\
\hline $\begin{array}{l}\text { Manage } \\
\text { Curriculum }\end{array}$ & $\begin{array}{l}\text { Set-up module for different curriculum per } \\
\text { program. }\end{array}$ \\
\hline $\begin{array}{l}\text { Manage } \\
\text { Subjects }\end{array}$ & $\begin{array}{l}\text { Set-up different subject offerings per } \\
\text { curriculum per program. }\end{array}$ \\
\hline \multicolumn{2}{|c|}{ Transaction Module } \\
\hline $\begin{array}{l}\text { Subject } \\
\text { Registration }\end{array}$ & $\begin{array}{l}\text { Register/edit subjects offering of the current } \\
\text { semester. Bulk enlistment imported from } \\
\text { the available subject matter list extracted } \\
\text { from the Student Information and } \\
\text { Accounting System (SIAS). }\end{array}$ \\
\hline $\begin{array}{l}\text { Faculty } \\
\text { Registration }\end{array}$ & $\begin{array}{l}\text { Enlist/edit faculty information; bulk } \\
\text { enlistment imported from the available } \\
\text { faculty master list obtained from the SIAS. }\end{array}$ \\
\hline $\begin{array}{l}\text { Manage } \\
\text { Schedules }\end{array}$ & $\begin{array}{l}\text { Register/edit class schedules; Faculty and } \\
\text { student class schedules imported from the } \\
\text { available schedule of classes from the SIAS. }\end{array}$ \\
\hline \multicolumn{2}{|c|}{ Report Module } \\
\hline $\begin{array}{l}\text { Evaluation } \\
\text { Summary }\end{array}$ & $\begin{array}{l}\text { The PSET can generate evaluation reports } \\
\text { produced in portable document format like } \\
\text { the Summary Faculty evaluation, } \\
\text { Permanent and contract of service Faculty } \\
\text { Evaluation, and Individual Faculty } \\
\text { Evaluation per Subject Evaluated including } \\
\text { the comments/suggestions by the students. }\end{array}$ \\
\hline $\begin{array}{l}\text { List of } \\
\text { Enrolled } \\
\text { Students }\end{array}$ & $\begin{array}{l}\text { The system generates a masterlist of } \\
\text { students per subject. }\end{array}$ \\
\hline
\end{tabular}

\subsubsection{For the students}

For the students, Figure 7, and Figure 8 are sample screenshots of the PSET under the Student Account. The account shows necessary student information such as student number, student name, course, and college; the different subjects enrolled; and the teaching effectiveness 
Irma T. Plata et al., International Journal of Advanced Trends in Computer Science and Engineering, 9(1), January - February 2020,186 - 193

questionnaire. Table 7 presents the modules and their description.

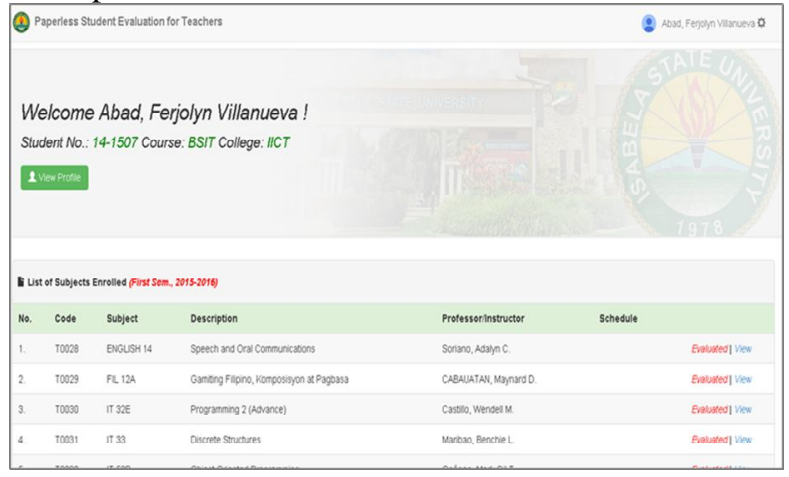

Figure 7: PSET student main form

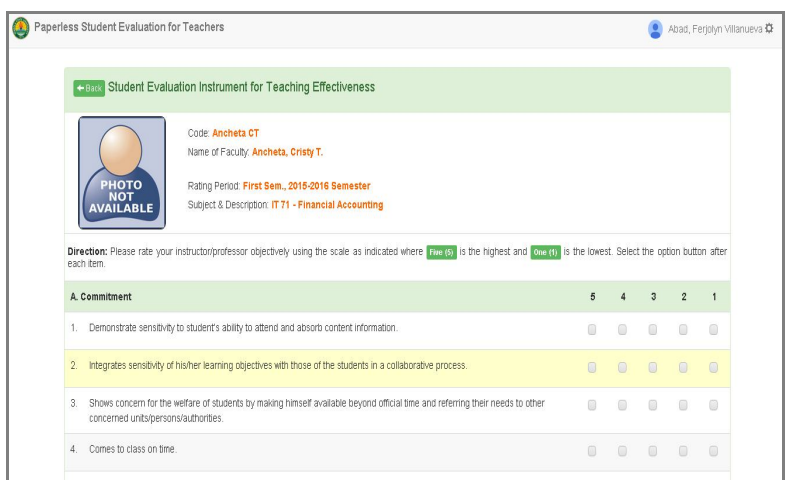

Figure 8: PSET student evaluation instrument for Teaching Effectiveness form

Table 7: Different components/modules of the PSET Transaction, Module for Students

\begin{tabular}{ll}
\hline Components & Description \\
\hline \multicolumn{2}{l}{ Set-up Module } \\
\hline View Profile & A student may opt to update his profile \\
\hline List of & Listing of subjects enrolled for the current \\
Subjects & semester imported from the SIAS. \\
Enrolled & \\
\hline $\begin{array}{l}\text { Evaluation } \\
\text { form }\end{array}$ & Answer the evaluation for Teachers' \\
\hline
\end{tabular}

\subsection{Pilot testing and parallel implementation of the system to determine issues on security of information, confidentiality, and anonymity of end-users}

The conduct of pilot testing and parallel implementation were in place to address the problems on security, confidentiality, and anonymity of users and information. Also, the recording of transaction trail/tracking and user's logging access in the system. The implementation of back-up plans to secure PSET data and information by storing to external drive and DVD.

The adoption of the parallel testing method to protect the confidentiality of students' information and evaluation data provided by the students. There were 50 Information Technology students were involved in the testing phase to check whether unauthorized system users may access information and evaluation provided. The system ensures the anonymity of students' identity and information provided. Additionally, stripping of students' identity as soon as they log off from the system. Although the system can keep track of the student's status, whether he/she already filled-up the evaluation form and responses were confidential and anonymous, a tracker is available to trace if the evaluation is completed.

\subsection{System Implementation}

During the implementation phase, configuration and enabling the security features were set, install the system to computer laboratories, and obtains a formal request to the higher management to operate the PSET for implementation. The performance of design reviews and system tests before placing the system into operations.

\subsection{PSET Usability Evaluation}

Table 8 shows the summary percentage ratings, and the highest with $83.6 \%$ rating is the overall satisfaction of students in using PSET. Followed by the PSET is easy to use $(83.1 \%)$, and the PSET is useful $(83.1 \%)$. Although it was rated "strongly agree," lower percentage ratings were noted on Questions, saving more time when PSET was used (74.9\%), and the PSET is user-friendly (75.8\%).

Table 8: Summary of Percentage ratings of the PSET Usability Evaluation

\begin{tabular}{|c|c|c|c|c|c|c|}
\hline & Indicators & $\begin{array}{c}\text { SA } \\
5\end{array}$ & $\begin{array}{l}\text { A } \\
4\end{array}$ & $\begin{array}{l}\mathrm{N} \\
3\end{array}$ & $\begin{array}{l}\mathrm{D} \\
2\end{array}$ & $\begin{array}{c}\text { SD } \\
1\end{array}$ \\
\hline 1 & $\begin{array}{l}\text { The PSET is } \\
\text { easy to use. }\end{array}$ & $83.1 \%$ & $15.1 \%$ & $1.5 \%$ & $0.2 \%$ & $0.1 \%$ \\
\hline 2 & $\begin{array}{l}\text { The PSET is } \\
\text { simple to use. }\end{array}$ & $80.5 \%$ & $16.8 \%$ & $2.5 \%$ & $0.2 \%$ & $0 \%$ \\
\hline 3 & $\begin{array}{l}\text { The PSET is } \\
\text { user-friendly. }\end{array}$ & $75.8 \%$ & $21.3 \%$ & $2.7 \%$ & $0.1 \%$ & $0.1 \%$ \\
\hline 4 & $\begin{array}{l}\text { I could } \\
\text { efficiently } \\
\text { complete the } \\
\text { evaluation tasks } \\
\text { using PSET. }\end{array}$ & $79.4 \%$ & $17.2 \%$ & $2.8 \%$ & $0.3 \%$ & $0.3 \%$ \\
\hline 5 & $\begin{array}{l}\text { It saves me more } \\
\text { time when I use } \\
\text { PSET. }\end{array}$ & $74.9 \%$ & $21.2 \%$ & $3.4 \%$ & $0.3 \%$ & $0.3 \%$ \\
\hline 6 & $\begin{array}{l}\text { The PSET is } \\
\text { useful. }\end{array}$ & $83.1 \%$ & $14.8 \%$ & $1.8 \%$ & $0.2 \%$ & $0.1 \%$ \\
\hline 7 & $\begin{array}{l}\text { I learned to use } \\
\text { PSET quickly. }\end{array}$ & $82.3 \%$ & $15.3 \%$ & $2.2 \%$ & $0.2 \%$ & $0.1 \%$ \\
\hline 8 & $\begin{array}{l}\text { I easily } \\
\text { remember how } \\
\text { to use PSET. }\end{array}$ & $80.8 \%$ & $16.6 \%$ & $2.3 \%$ & $0.2 \%$ & $0 \%$ \\
\hline 9 & $\begin{array}{l}\text { The interface of } \\
\text { the PSET is } \\
\text { pleasant. }\end{array}$ & $77.3 \%$ & $19.9 \%$ & $2.6 \%$ & $0.2 \%$ & $0.1 \%$ \\
\hline 10 & $\begin{array}{l}\text { Overall, I am } \\
\text { satisfied with } \\
\text { the PSET. }\end{array}$ & $83.6 \%$ & $13.6 \%$ & $2.6 \%$ & $0.1 \%$ & $0.1 \%$ \\
\hline
\end{tabular}

1. Based on the data, the majority of the student-respondents or $31 \%$ were freshmen. 
Irma T. Plata et al., International Journal of Advanced Trends in Computer Science and Engineering, 9(1), January - February 2020,186 - 193

2. That the majority of $83.1 \%$ of the students answered that PSET is easy to use.

3. $80.5 \%$ of students also found out that PSET is simple to use as compared to the current system.

4. There was $75.8 \%$ of students answered that PSET is user-friendly.

5. 79.4\% of the students answered PSET is efficient, and only $0.3 \%$ did not favor that PSET is efficient to use for evaluation.

6. There were $74.9 \%$ of students answered that when they used PSET, they saved more time as compared to paper and pencil evaluation.

7. There was $83.1 \%$ of students responded that PSET was very useful in evaluating teachers.

8. The majority of $82.3 \%$ of the students stressed that they quickly learned in using PSET in evaluating teachers.

9. Dominantly, $80.85 \%$ answered that PSET, when used, could easily be remembered.

10. $77.3 \%$ of the students answered that PSET's interface is pleasant to use.

11. $83.6 \%$ of the students responded that they were fully satisfied with using PSET for evaluation.

\section{CONCLUSION}

The information requirements identified in reviewing documents and reports about the present process flow of conducting teachers' evaluations by students significantly affect the analysis and design of the web-based PSET. The different functional requirements and non-functional requirements addressed the needs of the end-users taking into consideration the usual evaluation reports generated in the present system. The various designs related to the system, forms, and reports served as "blueprint" in the development of the system. The tangible outputs derived after the implementation of the PSET justify the functionalities in the system. These include teachers could receive ratings and feedback, including comments in a more timely manner. Second, students' feedback could be analyzed automatically. Third, the time allotted to students can provide them leeway to give their comments, and evaluation results are available electronically.

The development and implementation of the PSET to the Isabela State University served as an innovative tool of providing efficient academic service to the students, the workers of the University - the teachers, and the higher management of the University. The results of the usability evaluation reveal that the PSET strictly follows the criteria set based on standards set for System development and that students were satisfied in the implementation of the PSET.

\section{RECOMMENDATION}

The following are recommendations for future development/ enhancement of the PSET and other studies:

1. In the implementation, aside from using computers and laptops, mobile phones, tablets, or PDAs PSET must be used to cater a higher number of students during evaluation proper.

2. The generation of reports such as individual summary evaluation report; the ranking of teachers per College/Department/ Program; sending of teacher's evaluation reports to the teacher's e-mail; and the overall rating of the College to determine its overall standing must be a consideration.

3. The adoption of the PSET to eight more campuses of ISU System.

4. An empirical analysis of the students' evaluation using data mining techniques is another researchable area.

5. Sentiment analysis on the students' feedback toward their teacher classroom performance should be studied.

6. The evaluation of the social and economic efficiency of using the web-based PSET to determine its impact on the ISU community

\section{ACKNOWLEDGMENT}

We would like to acknowledge the Isabela State University through the Office of the University President for allowing and approving the implementation of the PSET in the 8 Colleges of ISU-Echague. To the VP-ARA, the University Director for Instruction, Executive Officer, Office of the ICT System, and the different Colleges of ISU-Echague Campus, especially to the ISU studentry. The Research and Development Division for approving and providing financial support to this kind of endeavor to realize the output of this study.

\section{REFERENCES}

[1] V.A. Zeithaml, "Consumer Perceptions of Price, Quality, and Value: A Means-end Model and Synthesis of Evidence," Journal of Marketing, 52, 2-22, 1988. https://doi.org/10.1177/002224298805200302

[2] H.M. Anderson, J. Cain, and E. Bird, "Online Course Evaluations: Review of Literature and a Pilot Study," American Journal of Pharmaceutical Education, 69(1), 34-43, 2005.

[3] C.J. Dommeyer, P. Baum, K.S. Chapman, and R.W. Hanna, "Attitudes of Business Faculty Toward Two Methods of Collecting Teacher Evaluations: Paper vs. Online," Assessment and Evaluation in Higher Education, 27(5), 455-462, 2002.

[4] B. Ravelli, "Anonymous Online Teaching Assessments: Preliminary Findings," Paper presented at Annual National Conference of the American Association for Higher Education, Charlotte, North Carolina, 2000.

[5] Isabela State University Website. Historical Background, https://isu.edu.ph/university-history-2/, 2018.

[6] C. Dommeyer, P. Baum, R. Hanna, and K. Chapman, "Gathering Faculty Teaching Evaluations by In-class and Online Surveys: Their Effects on Response Rates 
Irma T. Plata et al., International Journal of Advanced Trends in Computer Science and Engineering, 9(1), January - February 2020, 186 - 193

and Evaluations," Assessment and Evaluation in Higher Education, 29(5), 611-623, 2004.

https://doi.org/10.1080/02602930410001689171

[7] M. Kuhtman, "Review of Online Student Ratings of Instruction," College and University Journal, 80(1), 64-67, 2004.

[8] I.M. Taguiam, "Web-based Faculty Evaluation System of Apayao State College, Philippines," Philippine Association of Institutions for Research, Inc. Affiliate of Association for Institutional Research, USA. Retrieved from http://philair.ph/publication/index.php/irj/article/ view/367 on February 1, 2017. 2018. https://doi.org/10.7719/irj.v7i1.367

[9] M. McCollum, T. Cyr, and T.M. Criner, "Implementation of a Web-based System for Obtaining Curricular Assessment Data," Am J Pharm Educ. 67:1-3, 2003. https://doi.org/10.5688/aj670380

[10] R. Glotzbach, T. Burton, B. Co, R. Middleton, R., and R. Stremke, "A Web-Based Application for Online Instructor Evaluations," In R. Carlsen et al. (Eds.), Proceedings of Society for Information Technology \& Teacher Education International Conference 2007 (pp. 62-65). Chesapeake, VA: AACE, 2007. Retrieved from http://www.editlib.org/p/24502

[11] S.Z. Iqbal, "Z-SDLC Model: A New Model for Software Development Life Cycle (SDLC)," International Journal of Engineering and Advanced Research Technology (IJEART). 3. 1-8, 2017. https://www.researchgate.net/publication/316317334 _Z-SDLC_Model_A_New_Model_For_Software_Dev elopment_Life_Cycle_SDLC

[12] G. Elissavet, and A.A. Economides, "An Evaluation Instrument for Hypermedia Courseware," Educational Technology \& Society, 6(2), 31-44, 2003. 